\title{
Ketvirtokų anglų kalbos žodyno mokymosi pasiekimų ir motyvacijos didinimas: Quizlet ịrankio reikšmé
}

Evelina Streckienè ${ }^{1}$, Loreta Bukšnytè-Marmienè ${ }^{2}$

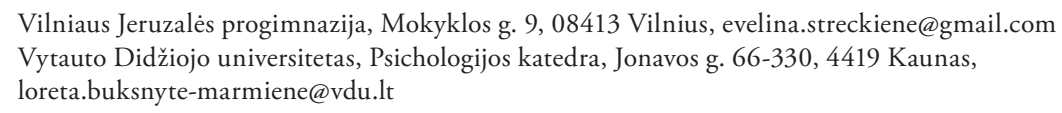

Anotacija. Straipsnyje analizuojama Quizlet įrankio reikšmė mokinių mokymosi motyvacijai bei pasiekimams mokantis anglų kalbos žodyno. Atliktas tyrimas parodė, kad naudojant Quizlet padidejo ketvirtokų mokymosi motyvacija: padidejo mokinių issitraukimas ir laiko, skiriamo anglų kalbos mokymuisi, dažnis bei trukmė, mokiniai išreiškẻ pozityvesnị požiūrị ir emocijas Quizlet atžvilgiu, palyginti su tradiciniu mokymosi būdu. Pasiekimų rezultatams Quizlet įdiegimas esminès reikšmès neturèjo.

Esminiai žodžiai: anglu kalbos žodynas, pasiekimai, mokymo(si) motyvacija, ịsitraukimas, požiūris, emocijos, Quizlet.

\section{Ivadas}

Šiuolaikiniame dinamiškame ir įvairovès pilname pasaulyje gebejjimas komunikuoti ivvairiomis kalbomis yra vertinga asmens kompetencija. Galimybė Lietuvos mokyklose jau pradinèse klasėse vaikams mokytis antrosios kalbos sukuria erdvę minètai kompetencijai formuotis. Vis dèlto mokant anglų kalbos pradinėse klasėse, susiduriama su problema, kad mokiniai nepakankamai motyvuoti mokytis nagrinejjamai temai aktualių anglų kalbos žodžių, neskiria pakankamai laiko ir dèmesio žodyno mokymuisi.

Daugelis užsienio mokslininkų (Setiawan ir Wiedarti, 2020; Utku ir Dolgunsöz, 2018; Uzun, Çetinavci, Korkmaz ir Salihoglu, 2013) teigia, jog tokių informacinių kompiuterinių technologijų (toliau - IKT), kaip žaidimų, viktorinų ar kitų ịrankių, naudojimas skatina 
mokinių įsitraukimą ir motyvaciją mokytis užsienio kalbos. Remiantis Bakhsh (2016) atliktu tyrimu, kūrybinių žaidimų naudojimas didina tikimybę išlaikyti pradinių klasių mokinių dèmesingumą ilgesnị laiką. Kadangi pradinių klasių mokiniai gali išlaikyti demesį trumpą laiką, veiklos turi būti kuo labiau ịtraukiančios (Bakhsh, 2016), o būtent tokios dažniausiai yra IKT aplinkoje modeliuojamos veiklos. Esant didelei mokinių motyvacijai mokytis anglų kalbos žodyno, tikètina, kad mokinių pasiekimai bus aukštesni (Setiawan ir Wiedarti, 2020).

Poreikis naudoti ịvairias IKT priemones ypač išryškejjo mokinius mokant nuotoliniu būdu Covid-19 pandemijos metu. Nors užsienyje IKT įrankiai naudojami gana plačiai, o jų efektyvumu neabejojama, Lietuvoje tai vyksta gana vangiai. Pasak Lisinskienès ir Kubiliūno (2021), 46 proc. apklaustų 70 Kauno miesto anglų kalbos mokytojų, dirbančių nuotoliniu būdu, nenaudoja jokių interaktyvių programų anglų kalbos užduotims kurti ir tik 9 proc. mokytojų naudoja tokias priemones kaip Quizlet.

Quizlet yra vienas iš tinkamų IKT įrankių mokyti(s) anglų kalbos žodyno, kadangi šis įrankis leidžia kurti mokomąsias korteles (angl.flashcards), pritaikyti jas pagal mokinių poreikị, pridèti asociatyvius paveikslèlius, ị mokymąsi integruoti žaidimo elementus, leisti mokiniams pasirinkti labiausiai patinkančias ir atitinkančias jų poreikius užduotis iš programèlès sukuriamų užduočiu ir žaidimų ịvairovès. Mokslineje literatūroje analizuojama Quizlet reikšmė mokinių pasiekimų rezultatams ir motyvacijai, tačiau tyrẻjų gautos išvados nevienodos. Kai kurie tyrẻjai padarẻ išvadą, kad Quizlet naudojimas padeda pagerinti pasiekimų rezultatus (Baptist, 2018; Chaikovska ir Zbaravska, 2020; Dizon, 2016; Montaner-Villalba, 2019; Sanosi, 2018; Van, Thuyet ir Thanh, 2020), o kiti tyrẻjai mano, kad Quizlet neturi reikšmingos įtakos pasiekimų rezultatams (Kálecký, 2016; Okkan ir Aydin, 2020; Skattenborg, 2020; Waluyo ir Bucol, 2020). Nera prieita prie vienos nuomonès ir dèl Quizlet reikšmès mokinių motyvacijai - tyrëjai Okkan ir Aydin (2020) nenustatė reikšmingo poveikio, kiti tyrèjai pabrěžia didelę Quizlet reikšmę motyvacijai (Baptist, 2018; Çinar ir Ari, 2019; Cunningham, 2017; Dizon, 2016; Kálecký, 2016; Setiawan ir Wiedarti, 2020; Skattenborg, 2020). Quizlet ịrankio naudojimas gali būti nevienodai efektyvus priklausomai nuo sociokultūrinio mokymo(si) konteksto - šalyse, kuriose IKT yra gana naujas reiškinys mokymosi procese, Quizlet ịrankio efektyvumas gali būti didesnis nei šalyse, kuriose IKT naudojimas yra ịprasta, kasdieninè veikla. Šio straipsnio autorių žiniomis, Lietuvoje nẻra atlikta tyrimo, vertinančio Quizlet ịrankio reikšmę mokinių motyvacijai ir pasiekimų rezultatams mokantis anglų kalbos žodyno. Taigi, nutarta atlikti tyrimą, kurio tikslas - išsiaiškinti Quizlet reikšmę ketvirtos klasės mokinių pasiekimams ir motyvacijai mokytis anglų kalbos žodyno.

Kèlème prielaidą, kad interaktyvaus ịrankio Quizlet naudojimas galètų motyvuoti mokinius atlikti užduotis, skatinti labiau įsitraukti į mokymąsi, mokiniai galimai paskirtų daugiau laiko ir ịdètų daugiau pastangų ị mokymosi veiklas, ir jų pasiekimų rezultatai taptų geresni. 


\section{Quizlet ịrankio reikšmė mokinių mokymosi motyvacijai bei pasiekimams}

\section{Mokiniu mokymosi motyvacija ir jos didinimo galimybès}

Motyvacija gali būti apibrèžiama kaip noras ar ketinimas, kuris gali paskatinti asmenị ką nors daryti, todèl motyvacija yra vienas svarbiausių veiksnių, darančių įtaką mokinių darbui ir lemiančių mokinių anglų kalbos žodyno mokymosi pasiekimus (Setiawan ir Wiedarti, 2020). Pasak Alizadeh (2016), motyvacija yra pagrindinis veiksnys, kuriuo galima paaiškinti bet kokios sudètingos veiklos sẻkmę arba nesèkmę - sẻkmingą užduoties atlikimą lemia tai, kad ją atliekantis asmuo yra motyvuotas. Todèl, padidinus mokinių motyvaciją, tikètinas ir pasiekimų rezultatų gerèjimas.

Mokinių motyvacija siejama su didesniu įsitraukimu ị mokymo(si) veiklas: kuo didesnè motyvacija, tuo stipriau mokinys ịsitraukia į mokymo(si) veiklas. Kaip pastebi Parsons ir Taylor (2011), įsitraukimo sąvoka apima daugiau negu tik pamokų lankymą ir akademinius pasiekimus. İsitraukę mokiniai įdeda pastangų, yra atkaklūs, savarankiškai siekia tikslo, išsikelia sau iššūkius ir mėgaujasi mokymosi procesu (Christenson, Reschly ir Wylie, 2012). Šio tyrimo kontekste kẻlème prielaidą, kad mokinių įsitraukimą í anglų kalbos žodyno mokymąsi atskleidžia mokinių i̇dedamos pastangos ir atkaklumas, o šias savybes galima ịvertinti per skiriamą laiką anglų kalbos žodyno mokymuisi ir savarankiškumą, atliekant šią veiklą.

Mokymo(si) motyvacijai ir informacijos apdorojimui daro ịtaką mokinio požiūris $\mathfrak{i}$ atliekamą veiklą ir su tuo susijusios emocijos. Kaip teigia Alizadeh (2016), motyvacija tai pastangų ir troškimo pasiekti kalbos mokymosi tikslų derinys ir tinkamas požiūris ị kalbos mokymąsi. Kashefian-Naeeini, Aminlari ir Mousavi (2018) nuomone, kai mokiniai neturi teigiamo požiūrio ị anglų kalbos mokymąsi, mokymosi procesas yra nevaldomas ir nesėkmingas, tai yra neatnešantis laukiamų rezultatų. Genc ir Aydin (2017) teigia, kad neigiamas požiūris ị kalbos mokymąsi gali demotyvuoti mokinius ir paskatinti juos atsisakyti kalbos mokymosi; teigiamas požiūris gali sąlygoti aukštą motyvaciją ir palengvinti mokymosi procesą. Mokiniai yra labiau linkę kreipti dèmeși, išmokti ir atsiminti ìvykius, vaizdus ir skaitytus tekstus, kurie sukelia emocinį atsaką arba kurie yra susiję su asmeniniais mokinių interesais (Woolfolk, Hughes ir Walkup, 2013).

Vis dèlto pati savaime mokinių mokymosi motyvacija dažniausiai neatsiranda, ją reikia sužadinti. Šiame procese labai svarbi yra mokytojo veikla. Norèdami paskatinti mokinių vidinę motyvaciją mokantis anglų kalbos, mokytojai turètų taikyti tokius mokymo(si) būdus ir metodus, kurie būtų patrauklūs ir malonūs mokiniams, motyvuotų mokinius ir padètų jiems labiau susidomèti anglų kalbos žodyno mokymusi (Alizadeh, 2016; Setiawan ir Wiedarti, 2020). Tyrejjai siūlo naudoti IKT tam, kad mokinių mokymo(si) veikla taptų veiksminga ir efektyvi. 
Šiuolaikiniai mokiniai labai domisi IKT, noriai atlieka interaktyvias užduotis interneto platformose, mėgsta naudotis išmaniaisiais įrenginiais. Pasak Rezaei, Mai ir Pesaranghader (2014), mobiliosios programèlès gali motyvuoti mokinius išmokti daugiau; mokiniams nuobodu mokyti(s) kartojimo ir ịsiminimo principu, todè ịvairių internetinių platformų naudojimas gali ne tik padèti mokytis, bet taip pat kelia jaudulị ir kuria įvairovę. Tai gali būti išnaudota jų mokymosi motyvacijai didinti, tai yra interneto platformose parengiant mokiniams patrauklias ir interaktyvias užduotis, kurias jie gali atlikti, naudodamiesi savo pasirinkta IKT priemone. Kuriant tokias užduotis svarbu suprasti, kad mokiniai yra motyvuoti mokytis tuomet, kai jie apie save galvoja kaip apie kompetentingus asmenis, dirba su medžiaga, pritaikyta jų lygiui, mato savo veiklos tikslą, suvokia, kad jų mokymasis yra svarbus, dirba saugioje aplinkoje, randa galimybę išreikšti psichologinị sẻkmės ir pripažinimo poreikị, mano, kad mokymasis yra reikalingas jiems, o ne jų mokytojams, dirba su įdomia medžiaga, turi galimybę priimti sprendimus ir jaučia atsakomybę dèl savo dalyvavimo, patiria daugiau sẻkmès negu nesèkmių (Alizadeh, 2016).

Apibendrinant galima teigti, kad motyvacija vaidina svarbų vaidmenį mokiniams mokantis anglų kalbos žodyno.

\section{Mokinių motyvacijos didinimas naudojant žaidimo elementus ir IKT}

Mokymasis žaidimo būdu padeda mokiniams aktyviai ịsitraukti ị procesą ir dalyvauti malonioje veikloje (Masri ir Najar, 2014). Vaikams nusibosta nuolat naudojami tie patys metodai, todèl reikalingos ịvairios smagios veiklos, norint ịtraukti mokinius ir išlaikyti jų dèmesị mokantis anglų kalbos (Ruzmetova, Orazova, ir Kayumova, 2020). Žaidimų privalumas, besimokant žodyno, yra tas, kad žaidimai motyvuoja, kadangi dažniausiai jie yra susiję su draugišku varžymusi ir kuria bendradarbiavimu paremtą mokymosi aplinką, - mokiniai turi galimybę mokytis kartu ir patirti bendrystę besimokydami (Derakhshan ir Khatir, 2015). Dolati ir Mikaili (2011) teigia, kad žaidimų naudojimas anglų kalbos pamokų metu ne tik pagerina mokinių pasiekimų rezultatus, bet ir motyvuoja bei ịtraukia mokinius, ypač ramius ir pasyvius, ị mokymosi procesą.

Anglų kalbos pamokose didelę naudą atneša netgi tradiciniai žaidimai, o skaitmeniniai ịrankiai yra dar naudingesni, ypač šiais laikais, kai yra lengva ir patogu juos įdiegti bei naudoti (Uzun, Çetinavci, Korkmaz ir Salihoglu, 2013). Harmer (2015) teigia, kad mokinių vidinei motyvacijai didelę ịtaką daro tai, kokias užduotis mes jų prašome atlikti. Pasak mokslininko, dažnai medžiaga ir veiklos, kuriomis prašome mokinių užsiimti, yra neįtraukiančios, monotoniškos, pavyzdžiui, mokinių motyvaciją gali slopinti vadovèlių, kaip pagrindinès ar vienintelès mokymo(si) priemonès, naudojimas. Harmer (2015) siūlo naudotis papildoma medžiaga ir ịtraukti mokinius ị veiklas, kurios būtų svarbios jų gyvenimui ir interesams, o tai galètų būti mokinių pamègtų įrenginių, tokių kaip mobilieji telefonai ir planšetès, naudojimas. Utku ir Dolgunsöz (2018) teigimu, mokant anglų kalbos, kaip užsienio kalbos, žodyno, vienas maloniausių mokymo metodų yra internetiniai žaidimai. Šių tyrejų nuomone, internetiniai žodyno mokymo žaidimai gali 
būti naudojami, papildant tradicinį mokymą iš vadovèlio, tokiu būdu didinant mokinių motyvaciją, mažinant mokinių nerimą ir mokymo(si) procesą priartinant prie šiuolaikinių mokinių poreikių. Tyrejų teigimu, tokių internetinių mokymo žaidimų taikymas mokymo(si) procese kuria pridètinę vertę, nes žaidimus mokiniai gali naudoti ne tik klasėje, bet ir savarankiškai, savo nuožiūra nepamokinėje aplinkoje.

Apibendrinant galima teigti, kad internetinių žodyno mokymo žaidimų naudojimas gali padidinti mokinių motyvaciją mokytis anglų kalbos žodyno bei pasiekimus.

\section{Quizlet ịrankio naudojimas mokiniu motyvacijai ir pasiekimams didinti}

Quizlet yra vienas iš IKT ịrankių, turintis mokymo žaidimų elementų ir galintis būti naudingas mokant(is) anglų kalbos žodyno. Quizlet užduotys yra kuriamos mokomųjų kortelių principu. Quizlet programèlè iš šių mokomųjų kortelių pati sukuria skirtingus užduočių tipus. Užduotys suskirstytos ị dvi kategorijas - „Study“ (liet. mokytis) ir „Play“ (liet. žaisti). Quizlet yra patogu naudoti mokiniams, mokantis angliškų žodžių, kadangi prie Quizlet galima jungtis tiek naudojant naršyklę, tiek įsidiegus mobiliąją programèlę (planšetiniame kompiuteryje ar mobiliajame telefone). Interneto naršyklèje naudojama Quizlet versija turi daugiau funkcijų, tačiau pažymètina, kad vaikai ne visuomet ịjungia kompiuterį, o mobilųji telefoną dažniausiai turi šalia. Mokiniai gali naudotis programèle kada tik panoreję, jei jie sinchronizavo žodžius su mobiliuoju telefonu, tokiu atveju žodžių mokymuisi nereikia interneto prieigos (Kálecký, 2016).

Quizlet naudojimas žodyno mokymui(si) vertintinas teigiamai, nes šiuo įrankiu sukuriama įvairovė užduočių, mokiniai gali pasirinkti, kurias užduotis jie nori atlikti ar nuo kurių pradèti, gali daugiau dirbti su tomis užduotimis, kurios jiems tinka ir patinka. Mokiniai gali varžytis tarpusavyje, stebèti savo mokymosi pažangą.

Quizlet - ịtraukiantis įrankis, kuris gali motyvuoti mokinius mokytis, naudojantis jo patogiomis interaktyviomis funkcijomis. Teigiama, kad Quizlet gali paskatinti mokiniu savarankiškumą ir ịsitraukimą mokantis užsienio kalbos (Cunningham, 2017), o tai savo ruožtu gali didinti mokinių pasiekimus. Galutinis kalbos mokymo tikslas yra mokinio igalinimas, kad mokinys galètų tobulinti savo užsienio kalbos ịgūdžius savarankiškai (Harmer, 2015). Naudodami Quizlet ịrankị mokiniai gali mokytis savarankiškai iš mokytojo pateiktos medžiagos - mokomųjų kortelių, taip pat jie gali jas kurti ir patys, papildydami mokomąją medžiagą ar sukurdami savo poreikius atitinkantị mokymosi rinkinị. Pasak Kálecký (2016), Quizlet ịrankis gali būti naudingas, skatinant mokinių savarankiškumą, kadangi jis iš esmès ir buvo sukurtas savarankiškam mokymuisi. Waluyo ir Bucol (2020) nustaté, kad anglų kalbos žodyno mokymasis naudojant Quizlet namuose priklauso nuo mokinių sąmoningumo, iniciatyvumo ir disciplinos.

Dauguma mokslininkų nustate teigiamą Quizlet reikšmę motyvacijai - Setiawan ir Wiedarti (2020) teigia, kad dauguma tyrime dalyvavusių mokinių jautėsi entuziastingiau, jiems nebuvo nuobodu, jie buvo labai įsitraukę, mokydamiesi žodyno su Quizlet, mokinių motyvacija mokytis anglų kalbos žodyno padidejo; Kálecký (2016) nurodo, kad 
dauguma profesinès mokyklos mokinių (77 proc.) teigè, jog smagu mokytis naudojant Quizlet; Çinar ir Ari (2019) tyrimo rezultatai rodo, kad mokiniai, naudojantys Quizlet anglų kalbos žodyno mokymuisi, demonstravo teigiamą požiūrị i anglų kalbos mokymąsi, Quizlet padidino mokinių susidomèjimą ir motyvaciją, palengvino žodyno mokymąsi, pamokos tapo smagesnės; Skattenborg (2020) nurodo, kad Quizlet naudojimas yra motyvuojantis ir gali būti naudojamas veiklai paįvairinti. Vis dèlto Okkan ir Aydin (2020) nenustatė Quizlet reikšmingumo motyvacijai. Tyrejjai samprotauja, kad tokie rezultatai gauti dèl to, kad anglų kalbos besimokančių studentų motyvacija mokytis žodyno yra apskritai aukšta, nepriklausomai nuo to, kokiu būdu jie mokosi.

Vertinant Quizlet ịrankio reikšmę mokinių pasiekimams, yra gaunami prieštaringi rezultatai. Kai kurie mokslininkai teigia, kad Quizlet padejo pasiekti geresnių mokymosi rezultatų - Montaner-Villalba (2019) nustatė, kad Quizlet ịrankị naudojančių mokinių testų rezultatai ženkliai pagerejo ir buvo homogeniškesni; Chaikovska ir Zbaravska (2020), Dizon (2016), Sanosi (2018) teigia, kad mokiniai naudodami Quizlet pasiekè geresnių rezultatų; Baptist (2018) nurodo, kad Quizlet padejo pagerinti žodyno rezultatus, ypač mokinių, turinčių specialiųjų poreikių. Kiti tyrèjai nenustatė reikšmingos Quizlet įtakos mokinių pasiekimų rezultatams (Kálecký, 2016; Okkan ir Aydin, 2020; Skattenborg, 2020; Waluyo ir Bucol, 2020).

Apibendrinant atliktą mokslo šaltinių analizę, galima teigti, kad IKT ir žaidimo elementų naudojimas padeda didinti mokinių motyvaciją ir pasiekimus mokant(is) anglų kalbos žodyno. Quizlet yra vienas iš įrankių, kurio funkcijos pritaikytos jị naudoti anglų kalbos žodyno mokymui(si). Šis įrankis siūlomas naudoti mokiniams mokantis anglų kalbos žodyno todèl, kad tai yra patrauklus mokiniams IKT įrankis, kuris suteikia galimybę mokytis kalbos žaidžiant. Vis dèlto tyrimų rezultatai vertinant šio įrankio efektyvumą mokantis anglų kalbos nėra vienareikšmiai. Daugiausia diskusijų keliantis klausimas yra dèl Quizlet reikšmès mokinių pasiekimų rezultatams, o didžiausia pozityvi Quizlet ịtaka nustatyta mokinių mokymo(si) motyvacijos ir ịsitraukimo ị anglų kalbos žodyno mokymą(si) didejimui. Šiame tyrime tikrinome dvi hipotezes:

- interaktyvaus ịrankio Quizlet naudojimas padidins mokinių motyvaciją mokytis anglų kalbos žodyno;

- interaktyvaus įrankio Quizlet naudojimas padès mokiniams pasiekti geresniu mokymosi rezultatu.

\section{Tyrimo organizavimas ir metodai}

Tiriamieji. Tyrime dalyvavo vienos Vilniaus miesto progimnazijos ketvirtos klasės mokiniai, besimokantys toje pačioje anglụ kalbos grupejje. Iš viso šioje grupejje yra 13 mokinių - 6 mergaitės ir 7 berniukai. Vaikų amžius yra 10-11 metų. Siekiant laikytis 
anonimiškumo ir konfidencialumo principų, rezultatų analizèje mokinių vardai ir pavardès neskelbiami, o kiekvienam tiriamajam ịvardyti priskirta kuri nors abėcèlès raidè.

Sudarant tyrimo imtị buvo taikomas patogiosios atrankos metodas. Iš anglų kalbą besimokančių mokinių grupių, patekusių i patogiosios atrankos imtị, buvo atrinkta tokia grupè, kurioje būtų tolygus tyrimo dalyvių pasiskirstymas pagal lytị ir kuo ịvairesnis pasiskirstymas pagal anglų kalbos pasiekimus. Pasirinktoje tyrimo dalyvių grupėje yra beveik po lygiai abiejų lyčių mokinių. Grupejje yra įvairių mokymosi lygmenų mokinių: vadovaujantis I pusmečio vertinimo rezultatais (tyrimas buvo atliekamas II pusmetyje) 5 mokinių pasiekimų lygis - aukštesnysis, 6 mokinių - pagrindinis, 2 mokinių - patenkinamas.

Tyrimo eiga. Atliekant tyrimą buvo vertinama Quizlet metodo reikšmè ketvirtos klasès mokinių pasiekimams ir motyvacijai mokytis anglų kalbos žodyno. Tyrimas vyko $2021 \mathrm{~m}$. pavasarị ir susidejjo iš šių etapų: (1) pirminès situacijos analizè, (2) naujo ịrankio anglụ kalbos žodyno mokymui(si) - Quizlet - taikymas, (3) situacijos po 5 savaičių mokymo(si) naudojant Quizlet analizė, (4) pirminès ir situacijos naudojant Quizlet palyginimas bei išvadų formulavimas.

Mokiniai tyrimo metu 5 savaites naudojo Quizlet ịrankị anglų kalbos žodyno aktualia tema (konkretaus vadovèlio skyriaus žodyno) mokymuisi. Siekiant įvertinti Quizlet reikšmę mokymesi, tyrimo metu buvo 2 kartus - prieš Quizlet įdiegimą ir inovacijos taikymo pabaigoje - vertinami mokinių pasiekimai ir mokymosi motyvacija ir atliekamas pirmojo ir antrojo vertinimo rezultatų palyginimas.

Quizlet taikymas anglu kalbos žodyno mokymuisi. Quizlet tinklalapyje buvo sukurta 50 mokomųjų kortelių, skirtų konkretaus vadovèlio skyriaus anglų kalbos naujiems žodžiams išmokti, pateikiant šių žodžių vertimus ir asociatyvius paveikslèlius. Toks sprendimas priimtas remiantis mokslininkų pastebejjimais, jog grafinis vaizdavimas ir nežinomų žodžių susiejimas su paveikslèliais suteikia privalumų mokantis anglų kalbos žodyno (Chaikovska ir Zbaravska, 2020). Quizlet programèle iš šiu mokomųjų kortelių sugeneravo ịvairias užduotis „Study“ ir „Play“ kategorijose. Inovacijos diegimo pradžioje mokiniams buvo pristatytos Quizlet funkcijos, jie buvo informuoti, kad gali nemokamai parsisiųsti Quizlet ị savo telefonus ar planšetes. Mokytojas gali stebėti mokinių pažangą Quizlet ir matyti, kada jie buvo prisijungę ir kokias užduotis atlikę. Tuo tikslu buvo sukurta virtuali klasė, prie kurios prisijungę mokiniai gavo mokomųjų kortelių rinkinị ir pradejo mokytis naujų žodžių, atlikdami užduotis "Study“ kategorijoje ir žaisdami žaidimus „Play“. Mokiniai namuose savarankiškai naudojosi itvairiomis užduotimis, kurias Quizlet sugeneravo iš mokymosi kortelių. Konkrečias užduotis iš visų užduočių ịvairovès ir jų atlikimo trukmę mokiniai galëjo pasirinkti patys pagal savo pomėgius, norus ir galimybes. Žodžių mokymasis yra ịprasta anglų kalbos dalyko namų darbų dalis, tačiau, užuot mokęsi iš popierinio žodynèlio (arba papildydami ši mokymosi būdą), mokiniai galejo naudotis ir buvo skatinami naudotis Quizlet interaktyvia platforma. Dirbant nuotoliniu būdu, sudètinga užtikrinti, kad mokiniai skirtų laiko ir pastangų 
naujiems žodžiams mokytis naudodami Quizlet (mokiniai mokèsi žodžių namuose, po pamokų), todèl pamokų metu kelis kartus buvo išbandytas mokinių įsitraukimą skatinantis žaidimas „Live“ (liet. gyvai). Žaidimo metu mokiniai gauna žodžius ar žodžių junginius lietuvių kalba ir turi pasirinkti tinkamą jų vertimą anglų kalba. Mokinių vardai užšifruojami, priskiriant gyvūnų pavadinimus. Mokytojo pabendrintame ekrane matoma kiekvieno „gyvūno“ pažanga. Mokiniai konkuruoja tarpusavyje pagal užduočių atlikimo laiką. Mokiniui suklydus, jo pažangos juostelè grị̌zta ị nulinę poziciją ir vèl pradeda kilti iš pradžių, teisingai atliekant užduotis. Žaidimo pabaigoje nurodomi trys pirmąsias vietas užèmę „gyvūnai“. Laimètojai noriai atskleidžia savo tikruosius vardus. O neužèmusiuosius prizinių vietų žaidimas motyvuoja labiau pasistengti ir tikètina, kad mokiniai namuose daugiau pasimoko, savarankiškai naudodamiesi Quizlet „Study“ ir „Play“ funkcijomis. Šiuo atveju Quizlet „Live“ žaidimu siekiama mokinius sudominti ir skatinti savarankiškai naudoti Quizlet namuose. Be to, ši smagi ir interaktyvi mokymosi patirtis padeda sukurti teigiamą mokinių požiūrio į žodyno mokymąsi pasikeitimą mokiniai pradeda suvokti, kad gali patirti sèkmę mokydamiesi žodyno, užuot įsivaizdavę žodyno mokymąsi kaip bauginančią užduotị (Wolff, 2016). Taip pat mokytoja stebejjo mokinių darbo su Quizlet statistinę informaciją ir primindavo apie įrankị skatindama mokinius ji naudoti.

Tyrimo metodai. Tyrimo metu buvo naudojami apklausos raštu ir apklausos žodžiu (interviu) metodai. Apklausa - duomenų rinkimo metodas, dažnai taikomas moksliniuose tyrimuose (Ponto, 2015). Šiame tyrime apklausos raštu ir žodžiu atlikimo būdas pasirinktas, atsižvelgiant į tyrimo tikslą ir objektą, tyrimo dalyvių skaičių ir turimus laiko bei materialinius išteklius. Apklausa priskiriama duomenų rinkimo strategijai, kurios galutinis rezultatas - tam tikru būdu susistemintų duomenų visuma; apklausa leidžia kiekybiškai aprašyti požymių reikšmių pasiskirstymą tiriamoje populiacijoje (Gaižauskaite ir Mikènè, 2014).

Mokiniu mokymo(si) motyvacijai vertinti naudoti šie tyrimo instrumentai:

1. E. Streckienès ir L. Bukšnytės-Marmienès parengta apklausos žodžiu (atliekamos interviu būdu) anketa. Apklausos žodžiu (interviu) būdo pasirinkimą sąlygojo tyrimo dalyvių amžius - savarankiškai raštu atsakinėdami ị klausimus jie galimai ne visus klausimus būtų supratę ir/arba ne į visus klausimus atsakę. Pasak Gaižauskaitès ir Mikènès (2014), atlikdamas tiesioginị interviu, klausẻjas gali fiksuoti ir neverbalinę informaciją, taip pat padèti tyrimo dalyviui suprasti klausimą, tyrejjas gali užtikrinti, kad bus užduoti visi klausimai ir stengiamasi gauti i juos atsakymus. Mokiniams buvo užduoti klausimai, susiję su anglų kalbos žodyno mokymosi ypatumais, skiriamu laiku, savarankiškumu, tèvų pagalba, mokymosi būdais, priemonemis ir kas mokiniams padeda mokytis žodyno, pvz., kaip mokotès nauju anglu kalbos žodžiu, kiek kartu per savaitę mokotés anglu kalbos žodžių, kiek laiko skiriate žodžiu mokymuisi, kas jums padeda mokytis nauju anglu kalbos žodžių? ir pan. Apklausos metu buvo siekiama išsiaiškinti, kiek mokiniai deda 
pastangų, kiek yra ịsitraukę ì anglų kalbos žodyno mokymąsi, manant, jog apie mokinių motyvaciją mokytis galima spręsti iš jų skiriamo laiko mokymuisi ir savarankiškumo (ar be tèvų priminimo ir pagalbos užsiima šia veikla). Mokinių atsakymai buvo užsirašomi iš anksto paruoštame apklausos protokole. Interviu metu gauti duomenys buvo grupuojami, skirstant mokinių atsakymus ị kategorijas, skaičiuojamas pasikartojančių atsakymų dažnis.

2. E. Streckienès ir L. Bukšnytės-Marmienès sudaryta anketa, remiantis Osgood semantinio diferencialo principu, kuri buvo naudojama mokinių požiūriui $\mathfrak{i}$ mokymą(si) ir emocijoms nustatyti. Mokiniams buvo pateiktas klausimas „Kaip jaučiatès, kai mokotės angliškų žodžių?" (atliekant apklausą antrą kartą, inovacijos taikymo pabaigoje - „Kaip jaučiatès, kai mokotės angliškų žodžių su Quizlet?"). Atsakant ị šị klausimą pateikta 17 bipolinių mokinių požiūrị ir emocijas apibūdinančių žodžių ar frazių (pvz., liūdesys - džiaugsmas, nuobodu - i̇domu, atidèlioju mokymąsi - nedelsdamas atlieku užduotis, nemalonu - malonu, sudètinga - paprasta, nekūrybinga - kūrybinga ir kt.). Mokiniai ịvardijo savo požiūrị, emocijas ir jų raiškos laipsni, pažymėdami vieną iš 7 galimų pozicijų (skalès vidurinè pozicija (4) išreiškia neutralią poziciją šių emocijų atžvilgiu, o kitų padalų žymèjimas reiškia stiprejjančią emocijos raišką link vienos iš dviejų priešingų jų reikšmių, kur 1 reiškia neigiamas emocijas, o 7 - teigiamas). Gavus vertinimus apskaičiuoti visų mokinių kiekvieno iš bipolinių žodžių ar frazių i̇vertinimų vidurkiai.

Mokinių mokymosi pasiekimams vertinti naudoti diagnostiniai testai (kontrolinių darbų žodyno dalis). Diagnostiniai testai buvo adaptuoti E. Streckienès, naudojantis ketvirtokų vadovèlio (Wetz ir Quinn, 2017) siūlomais testais, tačiau sukuriant daugiau užduočių, susijusių su išmokto žodyno patikrinimu. Diagnostinių testų žodyno daliai buvo skirti 55 iš 80 galimų testo taškų. Tyrimo metu diagnostinis testas buvo atliekamas 2 kartus: prieš Quizlet taikymą, mokiniams užbaigus tam tikrą vadovèlio skyrių (temą) buvo atliekamas diagnostinis testas iš tos temos žodžių; inovacijos taikymo pabaigoje mokiniams užbaigus vadovelio skyrių (temą), kurios žodžiams mokytis jie naudojo Quizlet įrankị, buvo atliekamas antras diagnostinis testas, susijęs su naujos temos žodžiais.

\section{Tyrimo rezultatai}

\section{Mokinių mokymosi pasiekimų ir motyvacijos mokytis anglų kalbos žodyno tradiciniu būdu analize}

Mokinių anglų kalbos žodyno mokymosi pasiekimų rezultatai analizuojami nustačius kiekvieno mokinio rezultatą ir paskaičiavus bendrą visos grupès vidurkị (žr. 1 lentelę). 


\section{1 lentelè}

Mokiniu pasiekimu rezultatai mokantis tradiciniu bū du

\begin{tabular}{clccc}
\hline Eil. Nr. & Mokiniai & $\begin{array}{c}\text { Surinkta taškų iš } \\
\text { žodyno dalies }\end{array}$ & $\begin{array}{c}\text { Maksimalus galimas } \\
\text { surinkti tašku skaičius }\end{array}$ & Rezultatas (\%) \\
\hline 1 & Mokinys A & 44,5 & 55 & 80,91 \\
2 & Mokinys B & 54 & 55 & 98,18 \\
3 & Mokinys C & 50 & 55 & 90,91 \\
4 & Mokinys D & 52,5 & 55 & 95,45 \\
5 & Mokinys E & 52 & 55 & 94,55 \\
6 & Mokinys F & 48,5 & 55 & 88,18 \\
7 & Mokinys G & 47 & 55 & 85,45 \\
8 & Mokinys H & 54 & 55 & 98,18 \\
9 & Mokinys I & 52,5 & 55 & 95,45 \\
10 & Mokinys J & 48 & 55 & 87,27 \\
11 & Mokinys K & 41,5 & 55 & 75,45 \\
12 & Mokinys L & 53 & 55 & 96,36 \\
13 & Mokinys M & 24,5 & 55 & 44,55 \\
& & & & 86,99 \\
\hline Vidurkis & & 47,85 & &
\end{tabular}

Iš pateiktos lentelès duomenų matome, kad mokiniai surinko nuo 24,5 iki 54 iš galimų 55 taškų žodyno dalyje (nuo 44,55 proc. iki 98,18 proc.), o bendras grupès vidurkis yra 47,85 taškai ( 86,99 proc.).

Apklausos žodžiu (interviu) metu paaiškèjo, kad dauguma mokinių anglų kalbos žodžiu ir jų vertimų mokosi iš mokytojos pateiktos medžiagos, savo sąsiuvinio, knygos, perrašo žodžius, tèvai klausinëja. Tačiau jokie IKT įrankiai, skirti būtent žodyno mokymuisi, nèra naudojami.

11 mokinių nurodè, kad jiems padeda tèvai, klausinèdami naujų žodžių, tai yra dauguma grupès mokinių nèra savarankiški. Analizuojant mokinių atsakymus ị klausimą apie anglų kalbos žodyno mokymosi namuose dažnĭ, pastebėta, kad mokymosi dažnis yra labai įvairus ir svyruoja nuo mokymosi kasdien iki 3 kartų per mènesį: 6 mokiniai mokosi naujų žodžių tik tuomet, kai mokytoja konkrečiai įvardija šią užduotị elektroniniame dienyne („tuomet kai užduota“; pažymètina, kad tai būna ne kiekvieną anglų kalbos pamoką, o tik tada, kai pamokos tema yra susijusi su žodyno plètimu, t. y. maždaug tris kartus per mènesį); 2 mokiniai mokosi anglų kalbos pamokos išvakarèse, t. y. 2 kartus per savaitę („tada, kai pamoka būna, kai lieka paskutinè diena iki anglų pamokos“); 1 mokinys - 1 kartą per savaitę; 4 mokiniai mokosi žodžių kasdien („aš po du žodžius vis kalu ir kalu ị galvą, jei turiu laiko"). Apibendrinant 6 mokinių, kurie mokosi kasdien 
arba bent du kartus per savaitę, ịsitraukimą galima ịvardyti kaip gana aukštą, o 7 - kaip žemą. Skiriasi ir mokinių vienos mokymosi sesijos trukmé: 5 mokiniai mokosi 5 min., 4 mokiniai - 10 min., 3 mokiniai - 15 min., 1 mokinys - 30 min.

Darytina išvada, kad mokiniai nèra itin savarankiški mokydamiesi žodyno, jiems reikia mokytojos ar tèvų priminimo ir pagalbos. Remiantis apklausos duomenimis pastebèta, kad mokiniai ịsitraukia ị savarankiškas veiklas tuomet, kai jiems ịdomu, tai yra pokalbiai anglų kalba su draugais, internetiniai žaidimai anglų kalba, youtube filmukai, mokiniai taip pat mielai ieško žodžių vertimo elektroninèje erdvèje. Didžioji šių veiklų dalis yra susijusi su IKT priemonių naudojimu, tačiau mokiniai neturi galimybès mokytis tam tikros vadovélio temos žodžių naudodami IKT priemones. Vadinasi, mokydamiesi anglų kalbos iš youtube, žaidimų ir kalbẻdami su draugais, mokiniai plète bendrąji, bet ne konkrečios temos žodyną.

Siekiant išanalizuoti mokinių požiūrị i m mokymąsi ir emocijas mokantis anglų kalbos žodyno tradiciniu būdu, t. y. prieš inovacijos diegimą, buvo apskaičiuotas kiekvienos iš bipolinių žodžių porų, sudarytų semantinio diferencialo principu, tiriamųjų atsakymų vidurkis, sudedant visų mokinių nurodytas reikšmes ir jų sumą padalijant iš visų dalyvavusių tyrime mokinių skaičiaus (žr. 1 pav.).

\section{1 paveikslas}

Mokiniu požiūris ị mokymą(si) ir emocijos mokantis anglų kalbos žodyno tradiciniu $b \bar{u} d u$

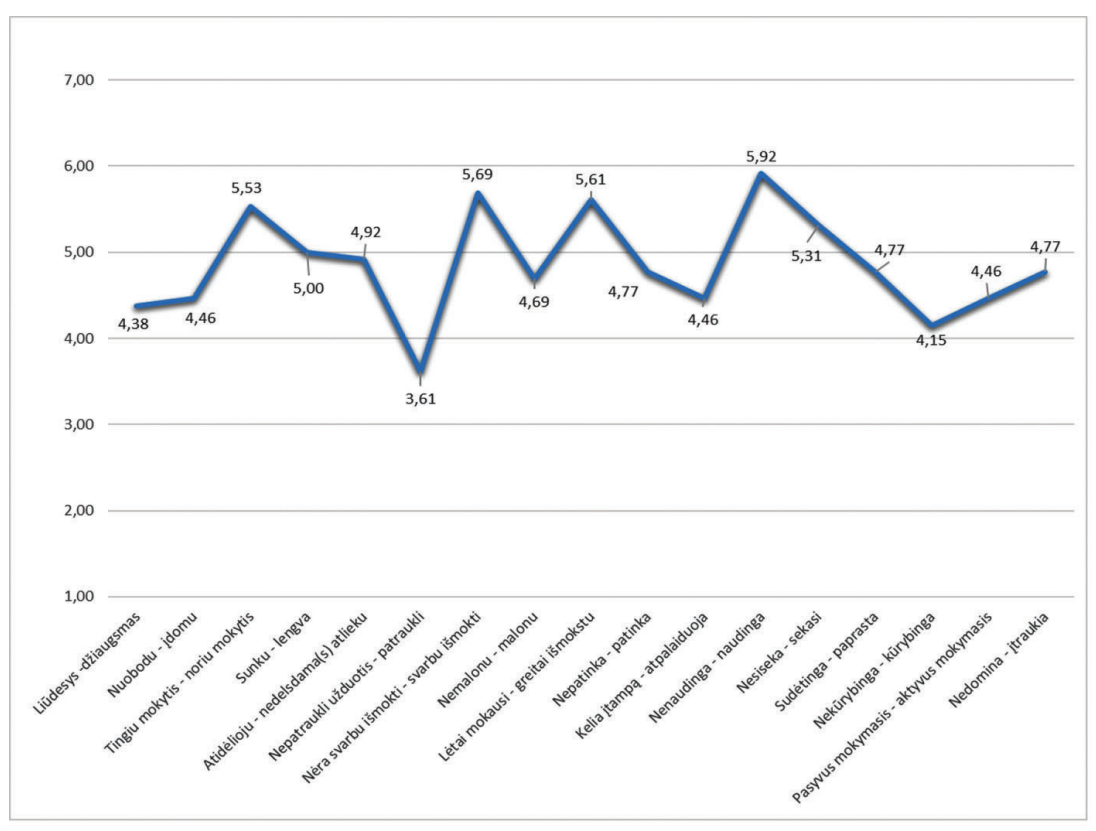


Matome, kad mokinių vertinimai skaleje nuo 1 iki 7 svyruoja nuo 3,61 iki 5,91 (bendras vertinimų vidurkis yra 4,85), tai yra vertinimai pasiskirstę tarp neutralių ir teigiamų. Žemiausiai ịvertintas užduočių patrauklumas - mokiniams nepatrauklu mokytis žodžių atmintinai iš mokytojos pateiktos medžiagos ar popierinio žodynèlio. Aukščiausiai įvertintas žodyno mokymosi naudingumas. Taigi, nors žodyno mokymosi užduotis nèra patraukli, mokiniai suvokia žodyno mokymosi naudą.

\section{Mokinių mokymosi pasiekimų ir motyvacijos mokytis anglu kalbos žodyno taikant Quizlet analizé}

Mokinių mokymosi pasiekimai buvo dar kartą įvertinti praejjus 5 savaitėms nuo Quizlet įrankio naudojimo pradžios ir palyginti su ankstesniais mokinių pasiekimais (žr. 2 lentelę).

\section{2 lentelè}

Mokiniu pasiekimu rezultatu palyginimas prieš inovacija ir įdiegus Quizlet

\begin{tabular}{|c|c|c|c|c|c|c|}
\hline $\begin{array}{l}\text { Eil. } \\
\text { Nr. }\end{array}$ & Mokiniai & $\begin{array}{c}\text { Surinkta } \\
\text { tašku prieš } \\
\text { inovaciją }\end{array}$ & $\begin{array}{c}\text { Surinkta taš- } \\
\text { kų idiegus } \\
\text { Quizlet }\end{array}$ & $\begin{array}{l}\text { Maksimalus } \\
\text { galimas su- } \\
\text { rinkti taškų } \\
\text { skaičius }\end{array}$ & $\begin{array}{c}\text { Rezultatas } \\
(\%) \text { prieš } \\
\text { inovaciją }\end{array}$ & $\begin{array}{c}\text { Rezultatas } \\
\text { (\%) ìdiegus } \\
\text { Quizlet }\end{array}$ \\
\hline 1 & Mokinys A & 44,5 & 49 & 55 & 80,91 & 89,09 \\
\hline 2 & Mokinys B & 54 & 54 & 55 & 98,18 & 98,18 \\
\hline 3 & Mokinys C & 50 & 47 & 55 & 90,91 & 85,45 \\
\hline 4 & Mokinys D & 52,5 & 41 & 55 & 95,45 & 74,55 \\
\hline 5 & Mokinys E & 52 & 48 & 55 & 94,55 & 87,27 \\
\hline 6 & Mokinys F & 48,5 & 46 & 55 & 88,18 & 83,64 \\
\hline 7 & Mokinys G & 47 & 45,5 & 55 & 85,45 & 82,73 \\
\hline 8 & Mokinys H & 54 & 55 & 55 & 98,18 & 100,00 \\
\hline 9 & Mokinys I & 52,5 & 54,5 & 55 & 95,45 & 99,09 \\
\hline 10 & Mokinys J & 48 & 51,5 & 55 & 87,27 & 93,64 \\
\hline 11 & Mokinys K & 41,5 & 22 & 55 & 75,45 & 40,00 \\
\hline 12 & Mokinys L & 53 & 46,5 & 55 & 96,36 & 84,55 \\
\hline 13 & Mokinys M & 24,5 & 46 & 55 & 44,55 & 83,64 \\
\hline \multicolumn{2}{|c|}{ Vidurkis } & 47,85 & 46,62 & & 86,99 & 84,76 \\
\hline
\end{tabular}

Iš pateiktos lentelès matome, kad mokiniai po inovacijos diegimo surinko nuo $22 \mathrm{iki}$ 55 taškų žodyno dalyje (nuo 40 proc. iki 100 proc.), o bendras grupès vidurkis sudare 46,62 taškus (84,76 proc.). Nors kai kurie mokiniai surinko daugiau taškų mokydamiesi 
su Quizlet, o vienas mokinys surinko 55 iš 55 galimų surinkti taškų, kai kurių mokinių pasiekimų rezultatai buvo žemesni nei rezultatai mokantis tradiciniu būdu. Bendras grupès vidurkis sumažèjo nuo 47,85 (mokantis tradiciniu būdu) iki 46,62 (naudojant Quizlet) taškų (nuo 86,99 proc. iki 84,76 proc.).

Apklausos žodžiu (interviu) metu paaiškèjo, kad daug mokinių vis dar mokèsi anglụ kalbos žodžių iš mokytojos pateiktos medžiagos, tačiau visi mokiniai atliko užduotis ir Quizlet programoje, tai galima matyti Quizlet pateikiamoje statistineje klasės aktyvumo informacijoje. Mokiniai noriai įsitrauke į žaidybines Quizlet veiklas, konkuruodami su bendraklasiais dèl rezultatų. Atsakydami ị klausimą apie žodyno mokymosi būdus, 3 mokiniai teigè, kad tèvai vis dar klausinėjo juos žodžių, norédami stebėti mokymosi eigą, tikrindami, kaip mokiniai moka žodžius, bet patys mokiniai neprašè tėų pagalbos. Tẻvai atliko kontrolę, bet neteike pagalbos. Kitų 10-ties mokinių žodžių mokymosi tèvai nekontroliavo.

Iš naudojamų pastarąji mẻnesį IKT priemonių anglų kalbos žodžiams mokytis mokiniai vienareikšmiškai nurodè daugiausia Quizlet, o mokantis tam tikros temos žodyno ši priemonè yra veiksminga, kadangi joje užduotys sukurtos tikslingai būtent tik su aktyvaus teminio žodyno žodžiais.

Mokymosi dažnis naudojant Quizlet buvo nuo 2 iki 6 kartų per savaitę: 1 mokinys žodyno mokèsi 6 kartus per savaitę, 2 mokiniai - 3 kartus per savaitę ir 10 mokinių 2 kartus per savaitę, tai yra mokiniai naudodami Quizlet mokèsi dažniau palyginti su žodyno mokymusi tradiciniu būdu. Analizuojant vienai mokymosi sesijai skiriamą laiką pastebėta, kad prieš įdiegiant Quizlet mokiniai mokèsi žodyno nuo 5 min. iki 30 min., o po Quizlet ịdiegimo - nuo 5 min. iki $60 \mathrm{~min}$. Sudejus visų 13 mokinių skiriamą laiką vienai žodyno mokymosi sesijai, prieš inovacijos diegimą gautume $140 \mathrm{~min}$. (5 mokiniai 5 min., 4 mokiniai - 10 min., 3 mokiniai - 15 min., 1 mokinys - 30 min.), po inovacijos diegimo - 270 min. (2 mokiniai - 5 min., 5 mokiniai - 10 min., 2 mokiniai - 15 min., 2 mokiniai - iki 30 min. ir 2 mokiniai - iki 60 min.) Taigi, mokiniai skyré beveik dvigubai daugiau laiko žodyno mokymuisi įdiegus Quizlet (žr. 2 pav.).

Apibendrinant apklausos žodžiu (interviu) gautų rezultatų palyginimą prieš inovaciją ir įdiegus Quizlet pastebėtina, kad išaugo mokinių savarankiškumas ir žodyno mokymuisi taikant Quizlet skirtas laikas (dažnis ir trukmè). Taip pat atkreiptinas dèmesys ị tai, kad mokymasis tapo ne toks chaotiškas, labiau tikslingas ir koncentruotas; dažniau buvo naudojamas Quizlet, kuriame užduotys buvo tikslingai susietos su mokymosi tema, palyginti su ankstesniu mokinių mokymusi iš įvairių atsitiktinių youtube filmukų ar internetinių žaidimų, tokiu būdu buvo plečiamas ne bendras anglų kalbos žodynas, o mokomasi žodžiu, susijusių su aktualia tema. 


\section{2 paveikslas}

Mokiniu žodynui mokytis skiriamo laiko mokantis tradiciniu büdu ir įdiegus Quizlet palyginimas

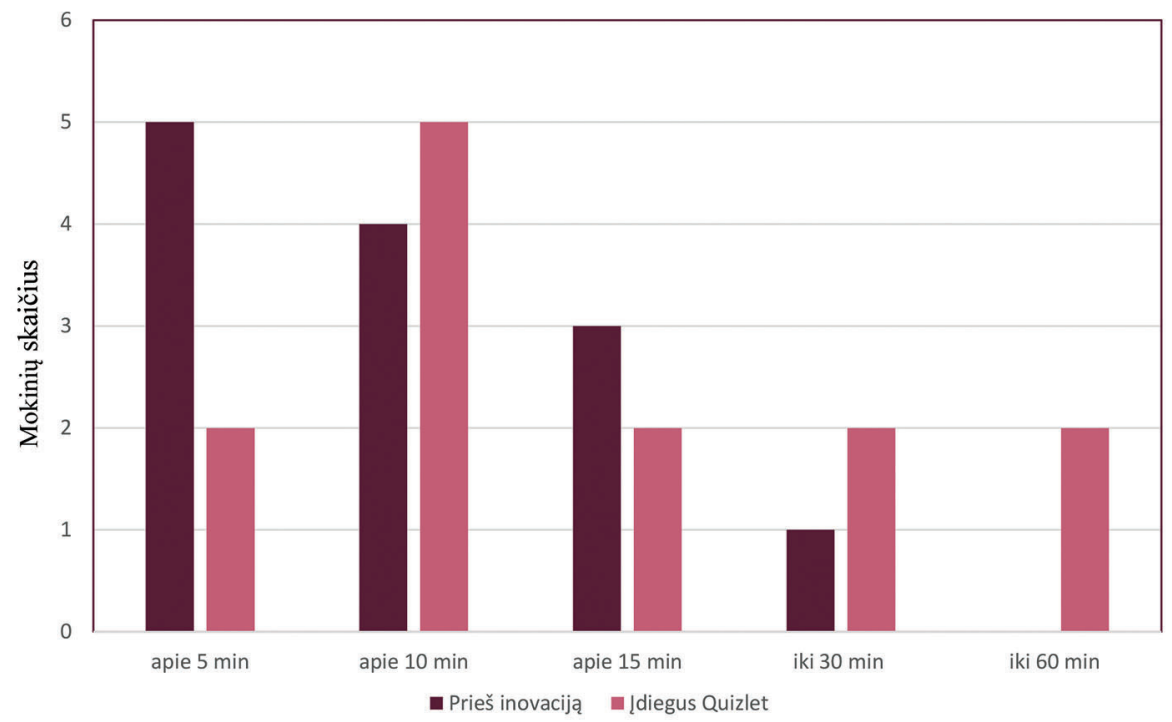

Mokinių požiūrio į mokymąsi ir emocijas naudojant Quizlet ịrankị rezultatų analizė atskleidè (žr. 3 pav.), kad mokinių vertinimai skalëje nuo 1 iki 7 svyruoja nuo 5,69 iki 6,69, tai yra dominuoja teigiami vertinimai. Žemiausiai, 5,69 balo, mokiniai vertino užduočių sunkumą (nors tai yra sąlygiškai žemiausias ịvertinimas iš visų, jis atspindi pozityvų mokinių požiūrị i užduotis), o aukščiausiai - tai, kad užduotys patinka ir jos įtraukia. Palyginome mokinių požiūrị i mokymąsi ir emocijas mokantis anglų kalbos žodyno tradiciniu būdu ir naudojant Quizlet metodą. Mokinių vertinimų vidurkis prieš inovaciją siekè 4,85 , o po inovacijos įdiegimo - 6,36. Taigi, mokinių vertinimai yra pozityvesni taikant Quizlet metodą lyginant su tradiciniu būdu.

Kaip galima pastebèti iš 3 paveiksle pateiktų rezultatų, didžiausias skirtumas yra vertinant užduoties patrauklumą - mokymosi procese, taikant Quizlet metodą, užduotys mokinių vertinamos kaip labiau patrauklios lyginant su užduotimis, mokantis tradiciniu būdu. Taip pat skirtumas stebimas mokinių vertinime, kiek užduotys yra kūrybingos Quizlet metodu mokantis užduotys vertinamos kaip labiau kūrybingos nei mokantis tradiciniu būdu. Svarbu, kad Quizlet metodu mokantis užduotys mokiniams kelia daugiau džiaugsmo palyginti su užduotimis, mokantis tradiciniu būdu. Mažiausias pokytis lyginant mokymąsi tradiciniu būdu ir taikant Quizlet įrankị stebimas mokinių vertinime, kiek jie lètai mokosi/greitai išmoksta, ir vertinant užduočių sunkumą/lengvumą. 


\section{3 paveikslas}

Mokiniu požiūrio ị mokymąsi ir emocijų mokantis anglu kalbos žodyno palyginimas prieš inovacija ir ịdiegus Quizlet
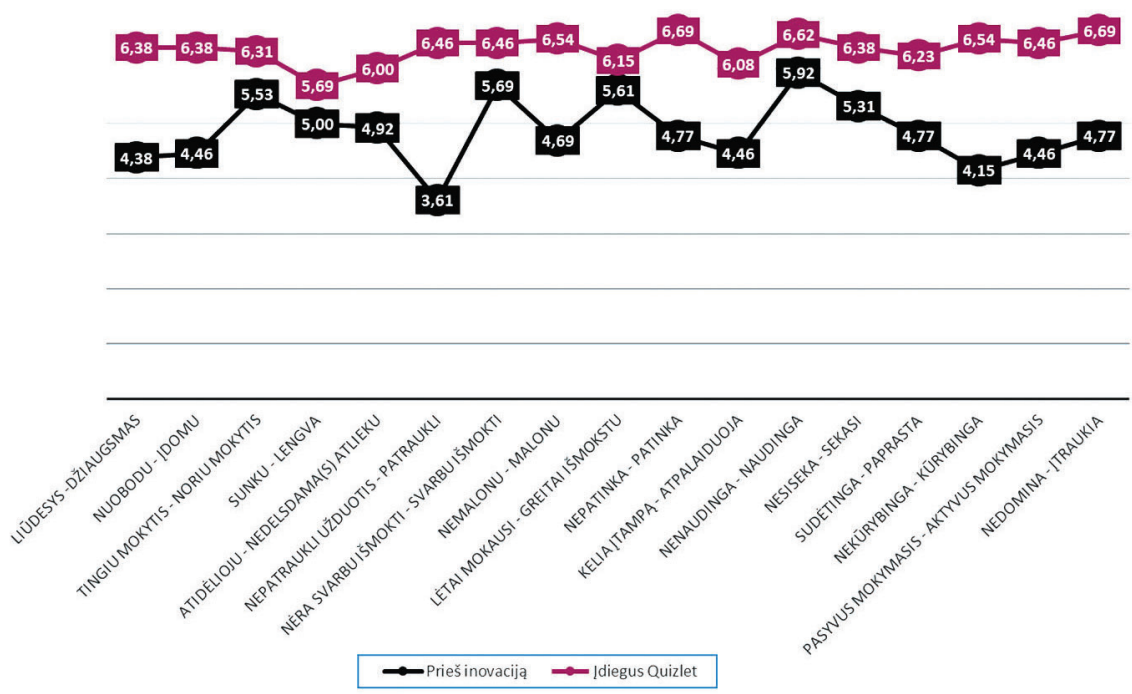

\section{Diskusija}

Quizlet metodo taikymas ketvirtokams mokantis anglų kalbos žodyno atskleidè i̇domius ir nevienareikšmius rezultatus. Mokinių pasiekimų rezultatai mokantis anglų kalbos žodyno tradiciniu būdu ir naudojant Quizlet įrankị vertinant bendrai (visos grupès rezultatus) skyrėsi minimaliai: naudojant Quizlet ịrankị ketvirtokų pasiekimai buvo minimaliai žemesni ( 84,76 proc.) palyginti su pasiekimų rezultatais mokantis tradiciniu būdu (86,99 proc.). Vertinant atskirų mokinių pasiekimus individualiai, 5 mokinių pasiekimų rezultatai pagerèjo, 7 - pablogejo, o 1 - nepakito. Šiuo aspektu tyrimo rezultatai sutampa su tyrëjų Okkan ir Aydin (2020), Kálecký (2016) ir Skattenborg (2020) išvadomis, kad mokymasis naudojant Quizlet nepadarė teigiamo poveikio mokinių pasiekimų rezultatams. Gauti rezultatai prieštarauja tyrëjų Chaikovska ir Zbaravska (2020), Montaner-Villalba (2019), Sanosi (2018) ir Van, Thuyet ir Thanh (2020) atliktų tyrimų rezultatams, kur tiriamųjų pasiekimų rezultatai pagerejo mokantis Quizlet ịrankiu. Taip pat tyrimo metu gauti rezultatai prieštarauja Montaner-Villalba (2019) išvadoms, kad mokantis naudojant Quizlet mokinių testų rezultatai homogeniškesni. Šio tyrimo metu mokantis tradiciniu būdu mokinių kontrolinių darbų žodyno dalies rezultatai buvo nuo 44,55 proc. iki 98,18 proc., o mokantis naudojant Quizlet - nuo 40 proc. iki 100 proc., taigi rezultatų diapazonas padidejo. 
Vertindami atskirų mokinių pasiekimų rezultatus, matome, kad mokinių A, H, I, J ir M rezultatai pagerejo, o mokinių C, D, E, F, G, K ir L rezultatai pablogejo, mokinio B rezultatai nepakito. Taigi, darytina išvada, kad kai kuriems mokiniams Quizlet metodas yra tinkamas ir veiksmingas. Atskirai aptartini du atvejai. Mokinio M pasiekimų rezultatai ženkliai pagerẻjo (prieš inovaciją tebuvo 24,5 taško, o naudodamas Quizlet mokinys surinko 46 taškus). Šiam mokiniui toks mokymo metodas buvo tinkamas ir efektyvus. Atkreiptinas demesys, kad mokinys patiria mokymosi sunkumus, ir šis atvejis atspindi Baptist (2018) tyrimo išvadas, kad Quizlet padejo pasiekti geresnių rezultatų didesnei daliai mokinių (70 proc.), turinčių specialiųjų ugdymosi poreikių, negu visų mokinių daliai (60 proc.). Būtent mokymosi sunkumus patiriančiam mokiniui Quizlet i̇rankis padejo pasiekti geresnių mokymosi rezultatų labiausiai. Vis dẻlto Quizlet padejjo pasiekti geresnių rezultatų tik 38 proc. tyrime dalyvavusių mokinių. Mokinio K pasiekimų rezultatai, atvirkščiai, pablogèjo. Vèliau paaiškejjo, kad mokydamasis nuotoliniu būdu mokinys K siekè atlikti kontrolinį darbą paskubomis, kad galètų kuo greičiau grị̌žti prie savo žaidimų. Mokydamasis kontaktiniu būdu mokinys būtų privalęjęs likti klasèje visą pamokos laiką, tad tikètina, kad būtų pasitikrinęs atliktas užduotis ir galimai būtų surinkęs daugiau taškų.

Minimaliai besiskiriantys mokymosi pasiekimų rezultatai mokantis tradiciniu būdu ir naudojant Quizlet galejjo būti paveikti ir tokių šalutinių kintamųjų, kaip tema, iš kurios rašomas kontrolinis darbas (galbūt vienos temos žodžiai vaikams buvo lengvesni ar labiau žinomi nei kitos temos), ar mokymosi naudojant Quizlet ịrankį laikotarpis (gal Quizlet taikymo mokymuisi laikotarpis buvo nepakankamai ilgas). Kaip teigia Cunningham (2017), siekiant mokinius paskatinti naudotis ịrankiu, reikalingas ilgesnės trukmès mokinių îtraukimas, neužtenka vien paminèti ar pademonstruoti įrankị vieną kartą, tikintis, kad mokiniai panaudos visas jo funkcijas ir naudos ši irankị savarankiškam mokymuisi.

Vertinant motyvaciją mokytis anglų kalbos žodyno, stebimas jos padidejjimas taikant Quizlet metodą. Iškelta prielaida, kad interaktyvaus ịrankio Quizlet naudojimas galètų motyvuoti mokinius atlikti užduotis, skatinti labiau ịsitraukti, mokiniai galimai paskirtų daugiau laiko ir įdètų daugiau pastangų, pasitvirtino. Taip pat padidejjo mokinių savarankiškumas ir iniciatyva: prieš inovacijos diegimą net 11 mokinių nurodè, kad jiems žodžių mokytis padeda tèvai, o po inovacijos diegimo tẻvų pagalbos ar priminimo nebereikejjo, mokiniai teigè patys atliekantys užduotis, nelaukdami tèvų ar mokytojo priminimo, neprašè tèvų pagalbos mokantis. Mokinių ịsitraukimą parodo padidèję mokymosi dažnis bei trukmè ir mokinių atsiliepimai interviu metu, kad su Quizlet yra ịdomiau ir lengviau mokytis, lengviau išmokti tarimą, tai kūrybingiau, patinka paveikslèliai, galima bet kada įsijungti. Šie tyrimų rezultatai sutampa su Cunningham (2017) ir Kálecký (2016) išvadomis, kad Quizlet yra tinkamas įrankis, siekiant paskatinti mokinių savarankiškumą ir įsitraukimą.

Mokinių paklausus, kas pasikeite anglų kalbos žodžių mokymesi, naudojant Quizlet ìrankị, atsiskleidè tokie mokinių pastebèjimai: „ídomiau mokytis“, „lengviau mokytis“, 
"geriau išmokti tarimą", „kūrybingiau“, „bet kada galima ịsijungti“, „gali žinoti, kaip tariasi“, „paveiksliukai patinka“. Tokie mokinių atsiliepimai patvirtina tyrejų Van, Thuyet ir Thanh (2020) atliktos mokinių apklausos, kurioje mokiniai nurode, kad Quizlet naudoti yra paprasta, lengviau ir greičiau mokytis naudojant šị îrankị, rezultatus.

Palyginus mokinių požiūrị i mokymąsi ir emocijas mokantis anglų kalbos žodyno tradiciniu būdu ir taikant Quizlet ịrankị, atsiskleidè palankesnis mokinių vertinimas Quizlet atžvilgiu: naudodami Quizlet mokiniai teige patiriantys daugiau džiaugsmo, užduotys jiems atrodo patrauklesnès ir kūrybiškesnès, mokytis įdomiau ir maloniau, mokymasis aktyvus ir įtraukiantis. Šie tyrimo metu gauti rezultatai sutampa su tyreju Baptist (2018), Dizon (2016), Setiawan ir Wiedarti (2020), Kálecký (2016), Çinar ir Ari (2019) ir Skattenborg (2020) išvadomis, kad Quizlet yra interaktyvus, motyvuojantis ir veiklą paįvairinantis įrankis, kurị naudodami mokiniai jaučiasi entuziastingiau, smagiau, labiau susidoméję.

Vis dèlto tam tikriems požiūrio į mokymąsi aspektams bei mokinių emocijoms skirtingi mokymosi būdai nebuvo labai reikšmingi - kai kurie mokinių vertinimai buvo labai panašūs tiek vertinant mokymąsi tradiciniu būdu, tiek vertinant mokymąsi taikant Quizlet ịrankį. Mažiausias pokytis lyginant mokymąsi tradiciniu būdu ir taikant Quizlet ịrankị stebimas mokinių vertinime, kiek jie lètai mokosi/greitai išmoksta, vertinant užduočių sunkumą/lengvumą, kiek svarbu/nesvarbu, naudinga/nenaudinga išmokti. Apibendrinant mokinių vertinimus galima teigti, jog nepriklausomai nuo taikomo mokymo(si) metodo mokiniai supranta, jog mokytis anglų kalbos žodyno yra svarbu ir naudinga, tačiau taikant Quizlet ịrankị užduotys mokiniams atrodo patrauklesnès ir kūrybiškesnès, labiau ịtraukiančios, o mokydamiesi jie patiria daugiau džiaugsmo, malonumo, jiems labiau patinka ir įdomiau lyginant su tradiciniu mokymosi būdu.

Užsienyje atliktuose tyrimuose atskleidžiamos panašios izžvalgos. Baptist (2018) atlikto tyrimo dauguma dalyvių nurodé, kad jiems patiko naudotis Quizlet programa. Kálecký (2016) tyrimo dalyviai teigè, kad Quizlet yra lengva ir smagu naudoti, paveikslèliai padeda ịsiminti žodžius, žaidimai padeda išmokti rašybą, tarimą ir priskirti tam tikriems žodžiams reikšmes. Skattenborg (2020) tyrimo dalyviai nurodè, kad Quizlet naudojimas motyvuoja ir yra smagus, tinka kartojimui. Setiawan ir Wiedarti (2020) tyrime mokiniai jaute daugiau entuziazmo naudodami Quizlet, jiems ši veikla nesukeldavo greitai nuobodulio, mokiniai buvo labiau susidomeję. Çinar ir Ari (2019) nurodo, kad mokymasis naudojant Quizlet mokiniams suformuoja pozityvų požiūrị i anglų kalbą ir jos mokymąsi. Visa tai rodo, kad Quizlet yra ne tik efektyvus, bet ir patrauklus bei smagus ịrankis mokiniams mokantis anglų kalbos žodyno.

\section{Tyrimo ribotumai ir galimos tolesnių tyrimų kryptys}

Didžiausias šio tyrimo ribotumas - labai maža tiriamųjų imtis, dèl to nebuvo galimybès taikyti statistinès duomenų analizės metodų. Dèl šios priežasties šio tyrimo rezultatai turètų būti vertinami ypač atsargiai. İ ši tyrimą galima būtų žvelgti kaip ì žvalgomąji, 
parengiamąji tyrimą platesniam, išsamesniam ir ilgesnị laikotarpị trunkančiam tyrimui, siekiant išsiaiškinti Quizlet ịrankio naudojimo reikšmę užsienio kalbų mokymuisi Lietuvos mokyklose.

Atliekant tokio tipo tyrimą, kuris pristatomas šioje publikacijoje, neįmanoma suvaldyti visų šalutinių efektų, galinčių turèti ịtaką tyrimo rezultatams. Šio tyrimo metu ịdiegus Quizlet įrankị nebuvo atsisakyta ir tradicinių mokymosi būdų, tad kyla klausimas, kiek po Quizlet ịdiegimo gauti mokinių rezultatai tiksliai atspindi būtent Quizlet įtaką mokinių pasiekimams. Šiame tyrime Quizlet poveikis mokinių pasiekimų rezultatams buvo vertinamas remiantis su dviem vadovèlio temomis susijusių diagnostinių testų rezultatais (iš vienos temos buvo testas mokantis tradiciniu būdu, iš kitos temos - testas mokantis naudojant Quizlet ịrankị). Gali būti, kad kažkuri viena iš šiu dviejų temų mokiniams pasirodè lengvesnè, nauji žodžiai žinomesni ar geriau įsimenami negu kitos temos. Taigi, tema galèjo būti tas šalutinis kintamasis, kuris pakreipe tyrimo rezultatus tam tikra linkme. Kadangi kiekvienas vadovèlio skyrius skirtas vis kitai temai ir mokiniai kaskart mokosi vis naujų žodžių, būtų tikslinga toliau naudojant Quizlet įrankị stebėti mokinių pažangą mokantis kitų temų žodžių.

Kitas su atliktu tyrimu susijęs diskutuotinas klausimas - atskirų tyrimo etapų vykdymo laikas ir trukmė, kurie galèjo turèti ịtakos tyrimo rezultatams. Pavyzdžiui, tyréjams kilo klausimų: kiek laiko reikètų naudoti Quizlet mokymosi procese, kad galima būtų vertinti jo efektyvumą; kada (po kiek laiko) ịdiegus Quizlet tikslingiausia vertinti mokinių pasiekimus ir pan.

Atkreiptinas dèmesys $\mathfrak{i}$ sunkumus, su kuriais mokytojai gali susidurti, diegdami Quizlet. Virtualios klasès statistine informacija, mokinių pažanga ir mokinių labiausiai pamėgta funkcija „Live“ yra tik mokamoje Quizlet versijoje. Taip pat reikia žinoti ir tai, kad kai kuriems ketvirtokams buvo sudetinga prisijungti prie Quizlet ir reikẻjo tèvų pagalbos. Taigi, diegiant ịranki gali būti reikalingas tèvų ịsitraukimas ir glaudus bendradarbiavimas.

Apibendrinant galima teigti, kad siekiant tikslesnių išvadų apie Quizlet įrankio reikšmę mokantis užsienio kalbų reikètų atlikti ilgalaikị tyrimą didesnẻje ir ịvairesnio amžiaus mokinių grupejje arba tyrime taikyti eksperimento metodą, siekiant sukontroliuoti šalutinius kintamuosius. Atliekant ilgalaikị tyrimą galima būtų ịvertinti, ar Quizlet poveikis mokinių pasiekimams ir motyvacijai yra ilgalaikis - gal pasibaigus naujumo efektui, baigiasi ir poveikis?

Nepaisant išsakytų tyrimo ribotumų, akivaizdu, jog mokiniai Quizlet vertino kaip patrauklų, įdomų, jiems patinkantị ir keliantị pozityvias emocijas ịrankị, todèl mokytojams, mokantiems užsienio kalbų, rekomenduojame ịtraukti šį įrankị ị savo mokymo priemonių arsenalą. Rekomenduotina išmokyti ir paskatinti mokinius patiems susikurti savo žodžiu korteles, tokiu būdu individualizuojant užduotis ir pritaikant konkrečių mokinių poreikiams. 


\section{Išvados}

Išnagrinëjus mokslo šaltinius, buvo nustatyta, kad Quizlet gali turèti reikšmę mokinių mokymosi motyvacijai ir pasiekimams. Remiantis šiomis prielaidomis ketvirtokų klasèje atliktas tyrimas, kurio metu paaiškejjo, kad mokinių pasiekimų rezultatai mokantis anglų kalbos žodyno tradiciniu būdu ir naudojant Quizlet ịrankị vertinant visos grupés rezultatus skyrèsi minimaliai: naudojant Quizlet ịrankị ketvirtokų pasiekimai buvo minimaliai žemesni ( 84,76 proc.), palyginti su pasiekimų rezultatais mokantis tradiciniu būdu (86,99 proc.). Vertinant atskirų mokinių pasiekimus individualiai 5 mokinių pasiekimų rezultatai pagerèjo, 7 - pablogèjo, o 1 - nepakito. Mokinių motyvacija mokytis anglų kalbos žodyno naudojant Quizlet padidèjo. Apieketvirtokų motyvacijos padidejjimą galime spręsti iš mokinių įsitraukimo padidèjimo, kurị rodo didesnis mokinių savarankiškumas, iniciatyvumas ir skiriamo laiko anglų kalbos žodžių mokymuisi didesnis dažnis bei trukmè, ir iš mokinių požiūrio į mokymąsi bei emocijų raiškos palyginimo mokantis anglų kalbos žodyno tradiciniu būdu ir taikant Quizlet metodą.

\section{Literatūra}

Alizadeh, M. (2016). The impact of motivation on English language learning. International Journal of Research in English Education, 1(11), 11-15. http://ijreeonline.com/files/sitel/ user files 68bcd6/admin-A-10-1-3-54f17e7.pdf

Bakhsh, S. A. (2016). Using games as a tool in teaching vocabulary to young learners. English Language Teaching, 9(7), 120-128. http://dx.doi.org/10.5539/elt.v9n7p120

Baptist, S. C. (2018). Effects of Quizlet on vocabulary mastery. Theses and Dissertations. 2555. https://rdw.rowan.edu/etc/2555

Chaikovska, O., \& Zbaravska, L. (2020). The efficiency of Quizlet-based EFL vocabulary learning in preparing undergraduates for state English exam. Advanced education, 7(14), 84-90. https:// doi.org/10.20535/2410-8286.197808

Christenson, S. L., Reschly, A. L., \& Wylie, C. (Eds). (2012). Handbook of research on student engagement. Springer Science \& Business Media.

https://books.google.lt/books?id=k3rf8 LgJQMC\&printsec=frontcover\&hl=lt\&source=g bs ge summary $\mathrm{r} \& \mathrm{cad}=0 \# \mathrm{v}=$ onepage $\& \mathrm{q} \& \mathrm{f}=$ false

Çinar, I., \& Ari, A. (2019). The effects of Quizlet on secondary school students' vocabulary learning and attitudes towards English. Asya Öğretim Dergisi, 7(2), 60-73. https://dergipark.org.tr/en/ download/article-file/913593

Cunningham, K. J. (2017). Quizlet for learner training and autonomy. Teaching English Reflectively with Technology, 123-135. https://members.iatefl.org/downloads/sigs/LTSIG ebook. pdf\#page $=124$ 
Derakhshan, A. \& Khatir, E. D. (2015). The effects of using games on English vocabulary learning. Journal of Applied Linguistics and Language Research, 2(3), 39-47. http://jallr.ir/index.php/ ЦALLR/article/view/40

Dizon, G. (2016). Quizlet in the EFL classroom: Enhancing academic vocabulary acquisition of Japanese university students. Teaching English with Technology, 16(2), 40-56. https://www. ceeol.com/search/article-detail?id=408428

Dolati, I. \& Mikaili, P. (2011). Effects of instructional games on facilitating of students' vocabulary learning. Australian Journal of Basic and Applied Science, 5(11), 1218-1224. https://www.researchgate.net/publication/216755496_Effects_of_Instructional_Games_on_ Facilitating of Students\%27 Vocabulary Learning

Gaižauskaitė, I., \& Mikėnė, S. (2014). Socialinių tyrimų metodai: apklausa. Vilnius: Mykolo Romerio universitetas. https://www3.mruni.eu/ojs/social-work/article/viewFile/362/350

Genc, Z. S. \& Aydin, F. (2017). An analysis of learners' motivation and attitudes toward learning English language at tertiary level in Turkish EFL context. English Language Teaching, 10(4), 35-44. http://doi.org/10.5539/elt.v10n4p35

Harmer, J. (2015). The practice of English language teaching. Harlow: Pearson Education Limited. Kálecký, R. (2016). Quizlet vs. vocabulary notebook: The impact of different methods of storing and revising vocabulary on students' progress, retention and autonomy. Brno: Masaryk University. https://is.muni.cz/th/qzvxl/Roman Kalecky - Quizlet vs.pdf

Kashefian-Naeeini, S., Aminlari, F. \& Mousavi, H. (2018). An investigation into attitudes towards learning English and the motivation type (Integrative vs. Instrumental) in Iranian students at Universiti Kebangsaan Malaysia. International Journal of English Language \& Translation Studies, 6(3), 204-213. https://eltsjournal.org/archive/value6\%20issue3/23-6-3-18.pdf

Lisinskienè, I. \& Kubiliūnas, R. (2021). Anglų kalbos mokymo nuotoliniu būdu metodika ir jos taikymas. Vilnius University Open Series, 53-63. https://doi.org/10.15388/LMITT.2021.6

Masri, A. A., \& Najar, M. A. (2014). The effect of using word games on primary stage students' achievement in English language vocabulary in Jordan. American International Journal of Contemporary Research, 4(9), 114-152. http://www.aijcrnet.com/journals/Vol 4 No 9 September 2014/17.pdf

Montaner-Villalba, S. (2019). The use of Quizlet to enhance vocabulary in the English language classroom. EuroCall 2019. Call and Complexity. Short papers from EuroCall 304-309. https:// books.google.lt/books?hl=lt\&lr=\&id=EHnCDwAAQBAJ\&oi=fnd\&pg=PA304\&ots=pvRniyU Wqd\&sig=-5MM4ArKs-tW0v3q2rjTh5ljqjg\&redir esc=y\# $\mathrm{v}=$ onepage\&q\&f=false

Okkan, A., \& Aydin, S. (2020). The effects of the use of Quizlet on vocabulary learning motivation. Language and Technology, 2(1), 16-25. https://dergipark.org.tr/en/pub/lantec/ issue/52176/662861

Parsons, J., \& Taylor, L. (2011). Improving student engagement. Current issues in education, 14(1). https://www.google.com/url?sa=t\&rct=j\&q=\&esrc=s\&source=web\&cd=\&ved=2ahU KEwib8u3X6ZzxAhUpi8MKHdzPCfEQFjABegQIBRAD\&url=https\%3A\%2F\%2Fcie.asu. 
edu\%2Fojs\%2Findex.php\%2Fcieatasu\%2Farticle\%2Fdownload\%2F745\%2F162\%2F0\&usg= AOvVaw1KNl akXp0Rn2LRxW3O0Bu

Ponto, J. (2015). Understanding and Evaluating Survey Research. Journal of the advanced practitioner in oncology, 6(2), 168-171. https://www.ncbi.nlm.nih.gov/pmc/articles/ PMC4601897/pdf/jadp-06-168.pdf

Rezaei, A., Mai, N., \& Pesaranghader, A. (2014). The effect of mobile applications on English vocabulary acquisition. Jurnal Teknologi, 68(2). https://doi.org/10.11113/jt.v68.2912

Ruzmetova, M., Orazova, F., \& Kayumova, G. (2020). The role of teaching vocabulary competence in English. Academic Research in Educational Sciences, 1(3), 509-513.

https://cyberleninka.ru/article/n/the-role-of-teaching-vocabulary-competence-in-english/ viewer

Sanosi, A. B. (2018). The effect of Quizlet on vocabulary acquisition. Asian Journal of Education and e-Learning, 6(4), 71-77. https://www.researchgate.net/profile/Abdulaziz Sanosi/publication/327108959 The Effect of Quizlet on Vocabulary Acquisition/ links/5b7a8aeb92851c1e12219602/The-Effect-of-Quizlet-on-Vocabulary-Acquisition.pdf

Setiawan, M. R., \& Wiedarti, P. (2020). The effectiveness of Quizlet application towards students' motivation in learning vocabulary. Studies in English Language and Education, 7(1), 83-95. http://www.jurnal.unsyiah.ac.id/SiELE/article/view/15359

Skattenborg, V. (2020). Using Quizlet for vocabulary learning - is Quizlet more effective and motivating than non-digital methods? [Master's thesis], 1-73.

https://hiof.brage.unit.no/hiof-xmlui/bitstream/handle/11250/2723664/Skattenborg Vibeke. pdf?sequence $=1$

Utku, Ö., \& Dolgunsöz, E. (2018). Teaching EFL vocabulary to young digital natives through online games: A study with Turkish 5th grade EFL learners. International Online Journal of Education and Teaching (IOJET), 5(1), 115-130. http://iojet.org/index.php/IOJET/article/ view/228/223

Uzun, L., Çetinavci, U. R., Korkmaz, S., \& Salihoglu, U. M. (2013). Developing and applying a foreign language vocabulary learning and practicing game: The effect of VocaWord. Digital Culture and Education. 5(1), 50-70. https://eric.ed.gov/?id=ED571553

Van, H., Thuyet, M. P. T. S., \& Thanh, M. H. N. (2020). Using Quizlet to enhance vocabulary acquisition of non-English major freshmen. Proceedings of the 8th Open TESOL International Conference 2020 http://opentesol.ou.edu.vn/2020conference.html

Waluyo, B., \& Bucol, J. L. (2020). The impact of gamified vocabulary learning using Quizlet on low-proficiency students. Computer-Assisted Language Learning, 22(1), 158-179. http://callej. org/journal/22-1/Waluyo-Bucol2021.pdf

Wetz, B., \& Quinn, R. (2017). English plus starter. Oxford: Oxford University Press.

Wolff, G. (2016). Quizlet live: The classroom game now taking the world by storm. The Language Teacher, 40(6), 25-27. https://jalt-publications.org/sites/default/files/pdf/the language teacher $/ 40.6$ tlt.pdf\#page $=27$

Woolfolk, A., Hughes, M., \& Walkup, V. (2013). Psychology in education. Harlow: Pearson. 


\title{
Increasing Fourth Form Students' Achievement Results and Motivation for Learning the English Vocabulary: The Impact of Quizlet
}

\author{
Evelina Streckienè ${ }^{1}$, Loreta Bukšnytè-Marmienè ${ }^{2}$ \\ 1 Vilnius Jeruzale Progymnasium, Mokyklos g. 9, LT-8413 Vilnius, evelina.streckiene@gmail.com \\ 2 Vytautas Magnus University, Department of Psychology, Jonavos g. 66-330, LT-44191 Kaunas, \\ loreta.buksnyte-marmiene@vdu.lt
}

\section{Summary}

The ability to communicate in a variety of languages is a valuable competence in the dynamic and diverse world. However, primary school students are not sufficiently motivated to learn English vocabulary. The research was carried out in order to assess the impact of the use of Quizlet on achievement results and motivation of the fourth form students to learn the English vocabulary.

The review of scientific resources deals with the possible impact of Quizlet on students' achievement results and motivation. The impact on achievement results is disputable among researchers. However, it was determined that Quizlet has a positive influence on the learning motivation and engagement of students in terms of time spent and autonomy as well as their attitude towards learning the English vocabulary and emotions experienced.

The empirical study compares the initial situation with the situation after the introduction and use of Quizlet. Students' achievement results were measured by means of diagnostic tests, and data on students' motivation were collected by means of survey (interview) (for measuring engagement) and semantic differential based survey (for measuring attitude towards learning and emotions). After using Quizlet for five weeks, students' learning motivation increased: an increase in students' engagement and a positive change of students' attitude and emotions were observed, although the innovation had no significant influence on achievement results.

Keywords: English vocabulary, achievement, learning motivation, engagement, attitude, emotions, Quizlet.

Gauta 20210709 / Received 09072021

Priimta 20211216 / Accepted 16122021 